\title{
Species Composition, Relative Abundance and Habitat Association of Birds in Arbegona, Garemba Forest, Southern Ethiopia
}

\author{
Ziyad Jemal $^{1} \quad$ Mustefa Sultan ${ }^{2}$ \\ 1.Oromia Forest and Wildlife Enterprise, Ethiopia \\ 2.Department of Forestry, College of Agriculture and Environmental Science, Arsi University, Asella, Ethiopia
}

\begin{abstract}
The present study was carried out in Arbegona Garemba forest from August June 2017 to February 2018 during wet and dry seasons. The study area was stratified based on vegetation composition. Accordingly, Modified habitat, Alpine bamboo forest, and Sub-Afro alpine /Ericaceous belt/ were considered. A line transects count aided by binocular was employed to investigate avian species diversity, relative abundance and Habitat association. Thus 10 transect lines of $0.75 \mathrm{~km}$ lengths with a width of $0.15 \mathrm{~km}$ or less wereused to cover $30 \%$ of the area. A total of 74 bird species consisting of 5 near endemics, 2 globally threatened and 3 Palearctic migrants were recorded.Average vegetation height was a good predictor for total bird abundance and bird species richness during dry season. Altitude accounted more in total species richness and bird species abundance during wet season. Though, slope was a good predictor for bird species abundance during dry season. It can be concluded that the patch of forest and its surrounding is an important bird area for migratory, endemic, and global threatened species. Therefore, it should be conservation priority area; hence, the study suggests that conservation together with ecotourism development is needed for its sustainability.
\end{abstract}

Keywords/Phrases: Avian species, Habitat types, Habitat association, Species similarity

DOI: $10.7176 / \mathrm{ALST} / 75-03$

Publication date:June $30^{\text {th }} 2019$

\section{INTRODUCTION}

\section{Background and Justification}

Ethiopia has rich biodiversity resources of which 2970 species are animals and between 6,500- 7,000 higher plants consisting of $12 \%$ endemics (EBI, 2015). Of the animal species 320 are mammals of which 36 are endemics, 926 bird species consisting of 24 endemics, 1,249 arthropods with 11 endemics, 200 fish with 40 endemics, 202 reptiles with 17 endemics and 73 amphibians with 30 endemics (EBI, 2015 and WeldemariamTesfahunegny,2016). Of these, birds are one of the most important components of biodiversity with ecological, economic and esthetic values. Birds are known as efficient and cost-effective insect pest controllers, Fruit-eating birds help in dispersal of seeds and seeds may sprout wherever the droppings fall and certain birds like hummingbirds and sunbirds pollinate flowers that produce nectar. Birds through the ages have been the source of considerable fascination and folklore and have been used as symbols (Clout and Hay, 1989).

The distribution and abundance of many bird species are determined by the composition of the vegetation or habitat (Lee and Rotenberry, 2005). Birds select habitats that fit their requirements for successful reproduction and survival though some generalist species may utilize several habitats (Rodríguez-Estrella, 2007). Besides habitat size, foraging modes and floristic composition have influence in the distribution of the species differences in requirement among bird species have caused specificity on habitat requirement (Buckley and Freckle ton, 2010). Despite the rich bird assemblages in Ethiopia, due to enormous habitat degradation and fragmentation many bird species including the endemic are threatened (Girma Mengesha et al., 2011).

Particularly, expansion of agriculture, livestock encroachment, deforestation, illegal fire, by the ever increasing human population has been often cited as the major cause of bird's habitat degradation, fragmentation and loss in Ethiopia ultimately affecting the survival of birds (Sekerciogluet al., 2012).Currently, due to land uses changes it is difficult to find forest habitat covering large areas. Most of the land has been converted to settlement and farmlands. Though no immediate threat is foreseen to the avian population, it could be resulted in deleterious effect on the overall ecosystem. Although there is better documentation of birds in protected areas, there are a few isolated reports of bird species diversity outside of protected areas in Ethiopia (Aerts et al., 2008). Comprehensive baseline information is lacking even for several of the endemic bird species. The status of birds in relation to habitat association in the present study areas is very little known. As a result, the present study is aimed to investigate species composition, relative abundance and habitat association of birds in Arbegona garemba forest. 


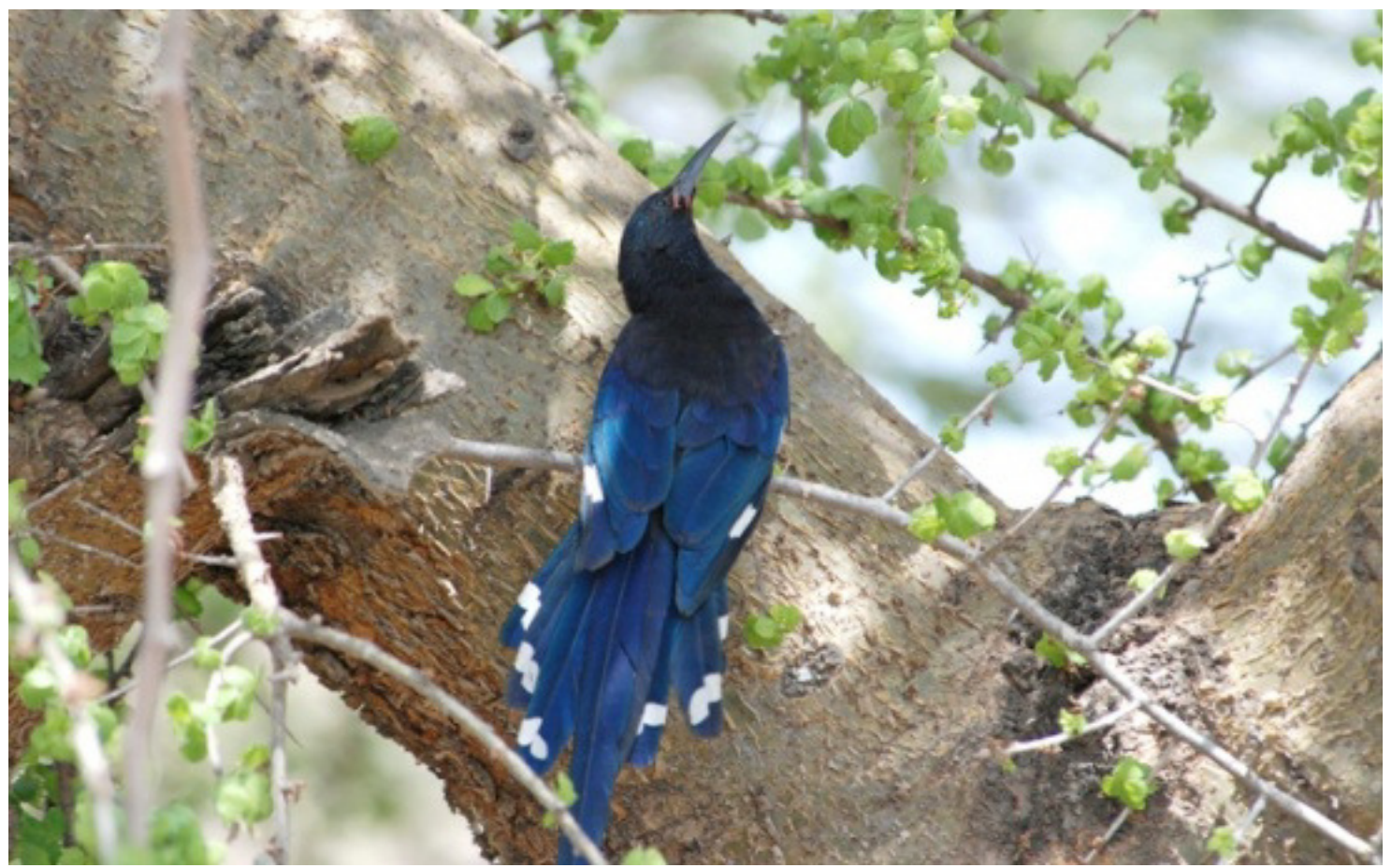

Figure 1. Black billed hoopoe

\section{MATERIALS AND METHODS}

\section{Description of the Study Areas}

The study was conducted in the Arbegona Garemba forest in Arbegona district in SNNP (Fig.1).

\section{Geographical Location}

Arbegona district is one of the districts in Sidama Zone of the Southern Nations, Nationalities, and Peoples' Region. It is bordered by Gorche district in North West, Kokosa district on the North and Bensa district on the East (Feleke Assefa et al., 2015). Arbegona district is located between $6^{\circ} 38^{\prime}-6^{\circ} 49^{\prime} \mathrm{N}$ and $38^{\circ} 34^{\prime}-38^{\circ} 49^{\prime} \mathrm{E}$ (Fig.1). Arbegona district is located $261 \mathrm{~km}$ South from Addis Ababa and $77 \mathrm{~km}$ South East from Hawassa town.
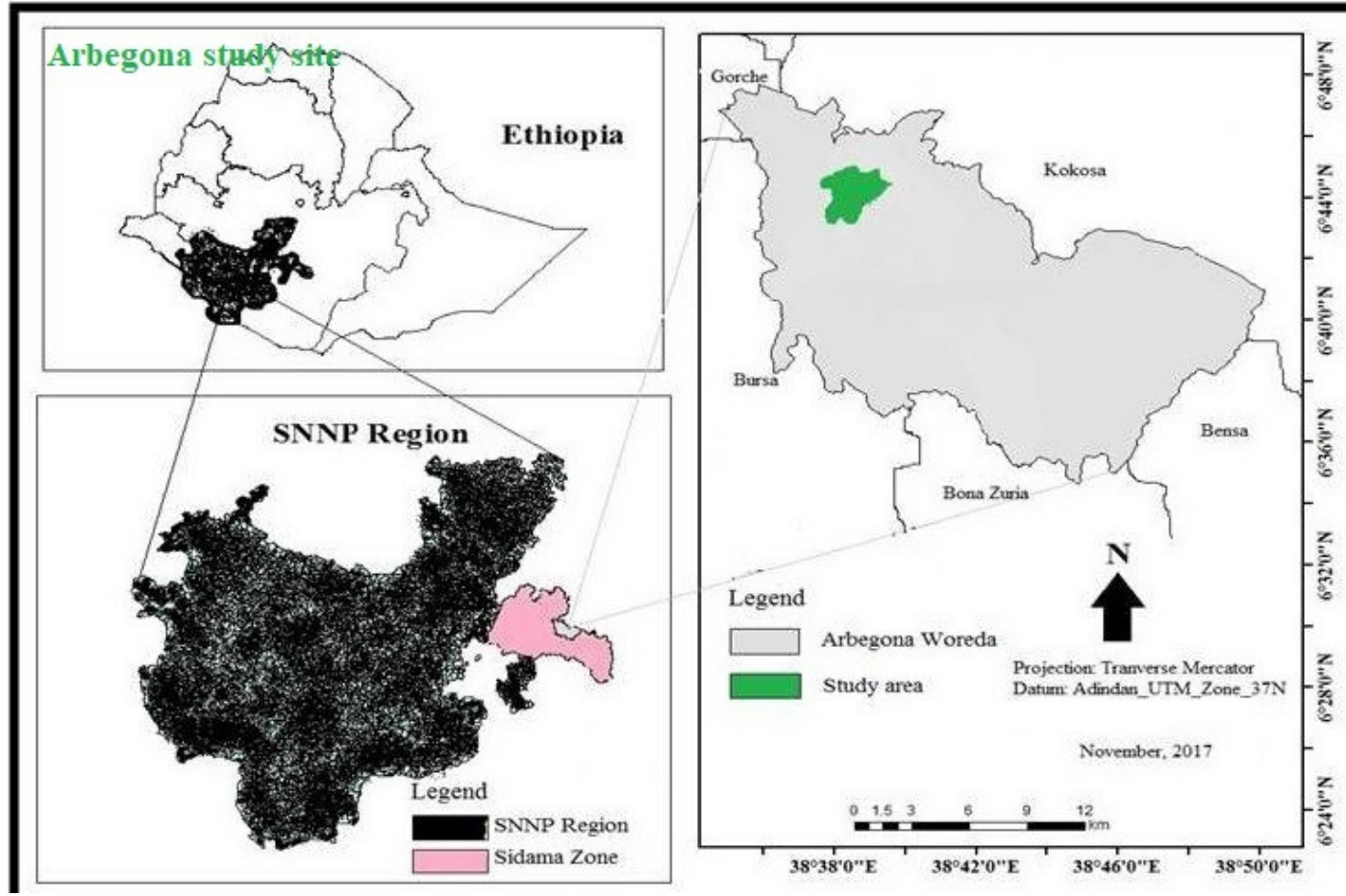

Figure 2: Location Map of Study Area 


\section{Topography and Climate}

Arbegona district is characterized by mountainous landscape having an altitude ranges from 2000ma.s.1 to 3336ma.s.l and 1500ma.s.1 to 3700ma.s.l respectively (FelekeAssefa et al., 2015). Thedistrict exhibits bimodal rainfall pattern.Arbegona district has a minor rainy season between the months of February to April and major rainfall between the months of July to October with an annual rain fall which ranges between 1250 to1300 $\mathrm{mm}$, the temperature ranges between a minimum of $14 \mathrm{C}^{\circ}$ and a maximum of $18 \mathrm{C}^{\circ}$ (AWAO, 2007).

\section{Flora and Fauna}

Alpine bamboo and moist evergreen Afromontane forest characterize the vegetation of Arbegona Garemba forest. Some ruminant trees such as Hagenia abyssinica, Juniperus procera,Olea africana, Hypericum revoltum and Erica arborea are dispersedly seen in the area, showing that in the past these species were the dominant vegetation cover in the middle and lower part of the area(AWAO, 2007).

Among the faunal species Fan-tailed raven (Streptopelia lugens), Thick billed raven (Galerida theklae), Alpine chat (Cercomela sordida), Mountain thrush (Turdusoli vaceus), Rupels robin chat (Cossyphase mirufa), Wattled ibis (Cinnyris venustus), Alpine swift (Tachymarptis melba), Dusky turtle dove (Tockusalboter minatus) and Red winged starling (Buphagusery throrhyncus) are some of the avifauna species found in Arbegona Garemba forest. The endemic mammals such as Menelik'sbush buck (Tragelaphus scriptus meneliki) are also found the Arbegona Garemba forest (AWCTO, 2009).

\section{Socio Economic Activity}

Arbegona district has a total population of 135,862 of whom 67,744 are men and 68,118 women; 6,745 or $4.97 \%$ of its population are urban dwellers (CSA, 2007). The major livestock reared in the Arbegona district were cattle, sheep, goats, mules, beekeeping, donkeys, horses and poultry (AWAO, 2007).

\section{METHODS}

\section{Reconnaissance Survey}

A reconnaissance survey was carried out during the second week of June, 2017for about one week to have basic information on accessibility, topography, infrastructures, and habitat stratification based on vegetation distribution and topographic nature for Arbegona Garemba forest. Furthermore, pilot survey was conducted at both study areas to test the applicability of the survey method, before the commencement of the actual data collection. For the pilot survey three transects in Arbegona Garemba forest was laid down and data collection was carried out.

\section{Sampling Design}

For this study, the Arbegona Garemba forest was stratified into three habitat types [modified habitat at the lower , Alpine bamboo forest at the middle and Sub Afro-alpine habitat (Ericaceous belt)] at the higher altitude following vegetation type and altitudinal gradient. In Arbegona Garemba forest, modified habitat represents areas with altitudes occurs from $3075-3165 \mathrm{~m}$ a.s.1. This habitat was disturbed habitat with livestock grazing and human encroachments. The Alpine bamboo habitat represents valley and middle altitude areas between 3189$3229 \mathrm{~m}$ a.s.l., and was dominated by highland Bamboo (Arundinaria alpina). This habitat was relatively intact and undisturbed compared to other habitat types. The Sub Afro-alpine habitat (Ericaceous belt) habitat covers the upland areas with rugged topography (3291-3305 m a.s.1.) and little remnants of Erica arborea at the summit of Mount Garemba and intermixed with predominantly scattered stands of trees like Hypericum revoltum, Giant lobelia and Arundinaria alpinain Arbegona Garemba forest.

Based on the reconnaissance survey, sampling transects was systematically generated in a geographic information system (GIS) using ArcGIS software v. 10.1 (ESRI, 2012) in the Arbegona Garemba forest. The total area of Arbegona garemba forest was $125,0000 \mathrm{~m}^{2}(1250 \mathrm{ha})$. Of these $30 \%$ (375ha) of the area were sampled. A stratified random sampling technique was employed in which transect placement was proportional to the area of the habitat types and represents each of the habitat types (Bibbyet al., 1998; Lambert et al., 2009, Shimelis Aynalem and Afework Bekele, 2008). Accordingly, a total of 10 transect lines, (Five (5) transects in modified habitat, four (4) transects in alpine bamboo forest and one (1) transect conducted in Sub Afro-alpine (ericaceous belt) habitat in Arbegona Garemba forest (fig.1). The distance between two adjacent transects was $0.25 \mathrm{~km}$ in Arbegona Garemba forest.

The length of each transect line was $0.75 \mathrm{~km} 1 \mathrm{~km}$ with a width of $0.15 \mathrm{~km}$ or less Arbegona Garemba forest. To avoid edge effect, transect lines were spaced 250m in Arbegona Garemba forest from the roadside (edge of the forest).

Line transect method was used since the study area is accessible and species can be detected along transect line. With line transect method it is possible to cover large areas and can generate more species richness efficiently (Bibby et al., 1992). Therefore, this method is very important since comprehensive baseline 
information and status of bird species in both Arbegona Garemba forest is lacking.

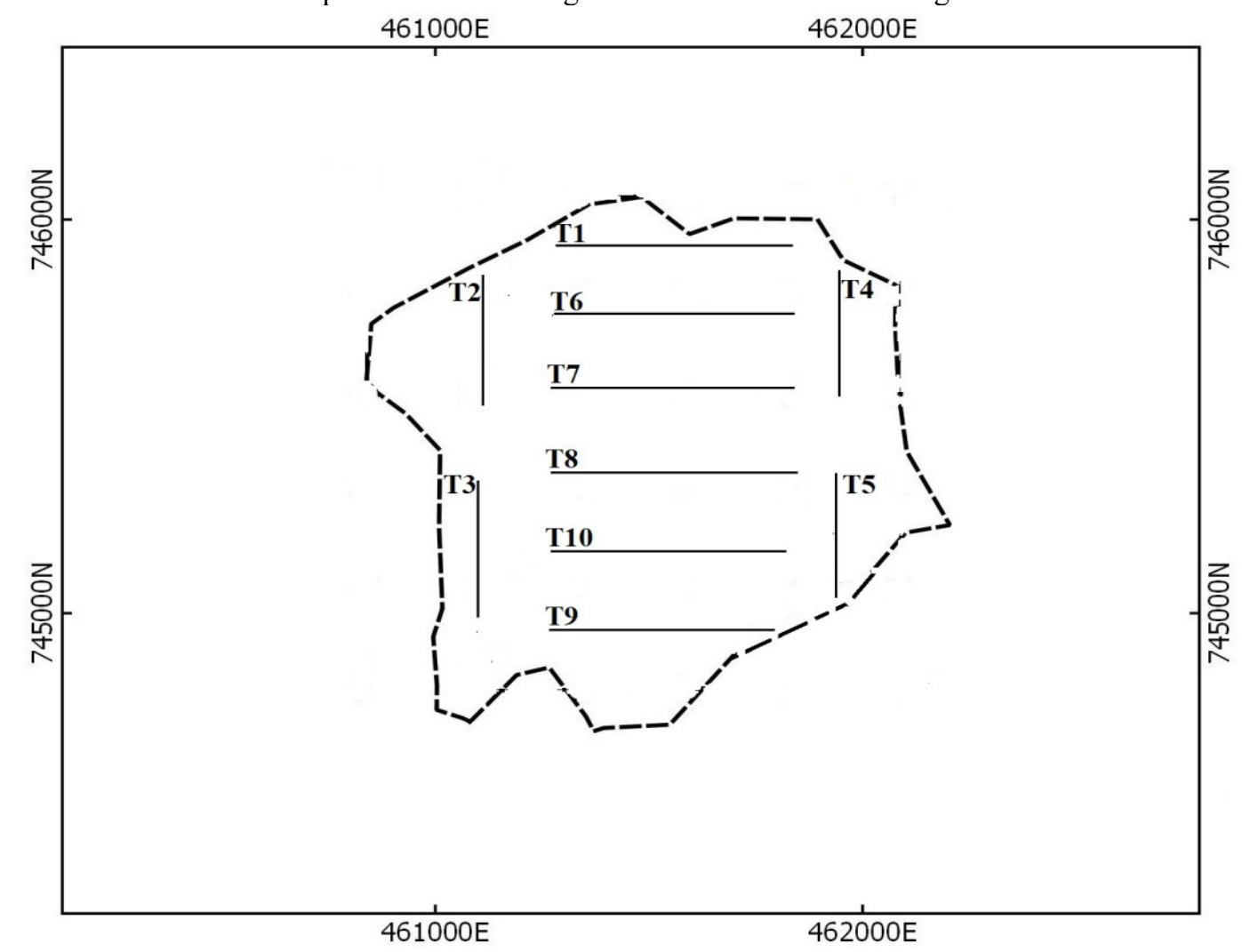

Figure 3: Line Transect Layout of Arbegona Garemba Forest

\section{Methodof Data Collection}

Data collection was carried out on foot walking along transect lines. Bird identifications and counting of individuals conducted by direct observations aided with naked eye and binoculars (10x50).

Sound records and photography were also taken for further confirmation by using Digital Camera. The associated vegetation types were also described and recorded. Location and distance of the observed birds was determined and recorded along transect lines using Geographic positioning system (GPS).

Each day of survey, arrive at the starting point approximately 20 minutes before sunrise so that counting can begin at sunrise to minimize the effect of time and weather conditions on bird detectability. Birds were counted when they were active in the mornings from 06:30-10:00h and in the afternoon from 15:30-18.00 $\mathrm{h}$ (Bibby et al., 1992). Unfavorable weather (strong wind or rain) was also being considered. A bird flying over the area was observed and recorded on data gathering worksheets to identify for species richness. For identification of species, plumage pattern, size, shape, color, songs and calls were considered as important parameters (Afework Bekele and Shimelis Aynalem, 2009). Songs and calls were used for identifying nocturnal species.

Supplementary data, such as elevation above sea level, latitude and longitude, vegetation type, average vegetation height of perching site for birds and percent slope inclination (flat Clinometers (Zerihun Girma et al., 2015).

\section{Method of Data Analysis}

All data was summarized per transect per habitat types during both dry and wet seasons by using table.

Moreover, Sorenson's similarity Coefficient (SOR) was equally calculated between pairs of habitats as: $\mathrm{SOR}=2 \mathrm{a} /(2 \mathrm{a}+\mathrm{b}+\mathrm{c})$ (Kent and Coker, 1992). Where $\mathrm{a}=$ number of species common to both habitat; $\mathrm{b}=$ number of species unique to habitat 1 ; and $\mathrm{c}=$ number of species unique to habitat 2 .

The stepwise regression analysis (backward elimination technique) model was carried out on the bird species richness and abundance both in wet and dry season as the outcome variable to evaluate parameters of the habitats that account for their disproportionate use. Model selection was based on F and P values.

Durbin-Watson statistic (D-W) and Variance inflation factor (VIF) were used to examine autocorrelation and multi collinearity of the predictor variables. Backward elimination continued until the "minimum F-toremove" dropped below the specified probability level (0.1). All computations were done by using SPSS version 20 and Past3 software 1.0 was used to calculate diversity indices. 
Percent relative abundance was calculated using formula $(\%)=\mathrm{n} / \mathrm{N} \times 100$ where, $\mathrm{n}$ is the number of individuals of particular species recorded and $\mathrm{N}$ is the total number of individuals of the species.

RESULTS

\section{Seasonal Relative Abundance}

A total of 618 individuals of birds grouped into 12 orders, 35 families and 74 species were recorded from Geremba mountain fragment (Appendix 1). Among the recorded species, Wattled ibis (Bostrychia carunculata), Thick billed raven (Corvus crassirostris), Alpine chat (Cercomelas ordida), Black winged love bird (Agapornista ranta) and Rouget's Rail (Rougetius rougetii) were endemic to Ethiopia and Eritrea in Geremba mountain fragment. Two globally threatened bird species i.e Hooded vulture (Psophocichlalit sipsirupa) was endangered and Rougets rail (Onychognathus morio) was near threatened bird species (IUCN red list, 2016) (Appendix 1).

Among the recorded bird species 71 were resident and 3 were Palearctic migrants in Geremba mountain fragment (Appendix 1). The order Passeriformes accounted, the highest number of families consisting 21 families and 43 species recorded in the Arebgona followed by the family Accipitridae with 9 species recorded and Sylviidae which had 5 species record (Appendix 1).

\section{Sorensen'sBird Species Similarity Index among the Three Habitat Types in Different Seasons}

In Arbegona Garemba forest the minimum value of bird species similarity between different vegetation for both seasons was recorded between Sub Afro-alpine and modified habitat while the maximum value was recorded between Alpine bamboo forest(0.11) and modified habitat with a value of 0.59 (Table 1 ).

Table 1: Bird Species Similarity of Arbegona Garemba forest among the Habitats and Seasons

\begin{tabular}{lcccccc}
\hline & \multicolumn{2}{c}{ Modified } & \multicolumn{2}{c}{ Alpine bamboo forest } & \multicolumn{2}{c}{$\begin{array}{c}\text { Sub Afro-alpine } \\
\text { (Ericaceous belt) }\end{array}$} \\
\cline { 2 - 8 } Habitat types & Dry & Wet & Dry & Wet & Dry & Wet \\
\hline $\begin{array}{l}\text { Modified } \\
\text { Alpine bamboo forest }\end{array}$ & 0.4 & 0.59 & - & - & & \\
$\begin{array}{l}\text { Sub Afro-alpine } \\
\text { (Ericaceous belt) }\end{array}$ & 0.11 & 0.23 & 0.25 & 0.51 & - & - \\
\hline
\end{tabular}

\section{Habitat Association}

The three habitat types (modified habitat, Alpinebamboo forest, and Sub Afro-alpinehabitat) had more or less similar species richness of birds

In Arbegona Garemba forest the vegetation height at interval of $0-5 \mathrm{~m}$ had the highest number of average species richness $(23.3 \pm 3.93, \mathrm{~N}=23)$ and individuals $(21 \pm 47.43, \mathrm{~N}=23)$ (Fig.3). While the least average species richness $(1.33 \pm 0.88, \mathrm{~N}=64)$ and individuals $(8.67 \pm 4.91, \mathrm{~N}=64)$ was recorded in vegetation height classes at interval of greater than ten meter $(>10 \mathrm{~m})$ in Arbegona Garemba forest (Fig.3).

There was significant difference in average species richness $(F 2,20=15, \mathrm{p}=0.000)$ and individuals $(\mathrm{F} 2,20$ $=7.942, \mathrm{p}=0.003$ ) between the vegetation height classes and bird species in Arbegona Garemba forest.

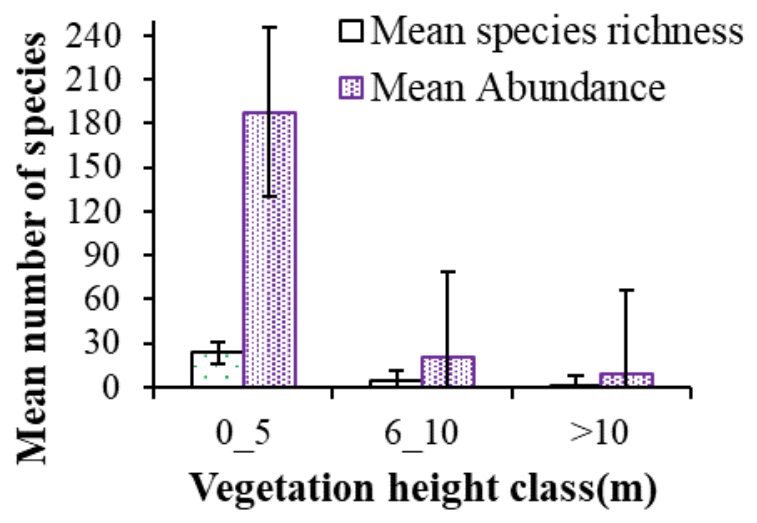

Figure 4:Mean species richness and abundance of birds across vegetation height classes of Arbegona Garemba forest.

In Arbegona Garemba forest,five models were eventually fitted that quantitatively and qualitatively explain which of the habitat components accounted for habitat association by the bird species. Habitat quality varied for both species richness and abundance during the wet and dry seasons in Arbegona Garemba forest. Average vegetation height was a good predictor for total bird abundance and bird species richness during dry season. 
Altitude accounted more in total species richness and bird species abundance during wet season. However, slope was a good predictor for bird species abundance during dry season in Arbegona Garemba forest (Table 2).

Table 2: Summary Statistics for Selected Models That Describe Habitat Association of Birds in Dry and Wet Seasons at Arbegona Garemba Forest

The Durbin-Watson statistic (D-W) and Variance Inflation Factor (VIF) were used to examine autocorrelation and multi collinearity of the predictor variables.

\begin{tabular}{|c|c|c|c|c|c|c|c|c|c|}
\hline \multirow[b]{2}{*}{ Model } & \multirow[b]{2}{*}{ Habitat variable } & \multirow[b]{2}{*}{ Coefficient } & \multirow[b]{2}{*}{$\mathrm{p}$} & \multirow[b]{2}{*}{$\mathrm{F}$} & \multirow[b]{2}{*}{ VIF } & \multicolumn{4}{|c|}{ Overall model } \\
\hline & & & & & & $\mathrm{p}$ & $\mathrm{S}$ & $\mathrm{R}(\%)$ & $\mathrm{D}-\mathrm{W}$ \\
\hline \multirow[t]{2}{*}{ BSRDS } & Constant & 8.772 & & & & 0.0443 & 5.066 & 27.5 & 1.22 \\
\hline & Av. Veg. height & -1.282 & 0.020 & 0.653 & 1.000 & & & & \\
\hline \multirow[t]{3}{*}{ BSADS } & Constant & 86.936 & & & & 0.0653 & 0.115 & 33.9 & 1.081 \\
\hline & Slope & -7.542 & 0.0130 & 0.969 & 1.000 & & & & \\
\hline & Av. Veg. height & -4.805 & 0.0710 & 0.846 & 1.081 & & & & \\
\hline \multirow[t]{2}{*}{ BSRWS } & Constant & 11.993 & & & & 0.0710 & 0.018 & 13.5 & 1.507 \\
\hline & Av. Veg. height & -0.788 & 0.0710 & 0.49 & 1.000 & & & & \\
\hline \multirow[t]{3}{*}{ BSAWS } & Constant & 93.967 & & & & 0.0253 & 0.325 & 24.1 & 2.066 \\
\hline & Av. Veg. height & -13.254 & 0.0708 & 0.492 & 1.579 & & & & \\
\hline & Altitude & -0.381 & 0.0140 & & 1.579 & & & & \\
\hline \multirow[t]{3}{*}{ TSR } & Constant & 10.507 & & & & 0.0816 & 0.55 & 19.8 & 1.483 \\
\hline & Av. Veg. height & -1.123 & 0.0600 & 0.497 & 1.821 & & & & \\
\hline & Altitude & -0.175 & 0.0119 & & 1.821 & & & & \\
\hline \multirow[t]{3}{*}{ TBA } & Constant & 84.617 & & & & 0.0158 & 0.195 & 44.2 & 1.643 \\
\hline & Av. Veg. height & -16.018 & 0.0132 & 2.064 & 1.821 & & & & \\
\hline & Altitude & -0.331 & 0.0910 & & 1.821 & & & & \\
\hline
\end{tabular}

BSRDS: Bird species richness dry season

BSADS: Bird species abundance dry season

BSRWS: Bird species richness wet season

BSAWS: Bird species abundance wet season

TSR: Total species richness

TBA: Total species abundance

\section{DISCUSSION}

In Geremba mountain fragment in terms of percent relative abundance both Yellow bellied waxbill (Coccopygia quartinia) and Alpine chat (Cercomelas ordida) had the highest relative abundance in modified habitat. The relative abundance of birds in the study area is related to the availability of food, habitat condition and breeding season of the species. Similar result was also obtained by Girma Mengesha and Afework Bekele (2008) who reported positive correlation between bird species richness and the availability of vegetation strata. Similarly, Chace et al. (2006) reported that birds respond to changes in vegetation composition and structure, which in turn affects their food resources.

Among the three habitat types, more similarity of birds' species was recorded from modified habitat and alpine bamboo forest both during dry $(\mathrm{SI}=0.4)$ and wet $(\mathrm{SI}=0.59)$ seasons. This is probably due to the adjacent occurrence of the two habitat types. Study carried out by Zerihun Girma et al. (2016), also showed significant correlation between similarity of bird species and the vegetation structure.

Therefore, similarity in floristic composition may account for the similarity in bird species between different vegetation types. The difference in species diversity, number of species and number of individuals of species among the different habitat types of the present study could be associated with differences in habitat characteristics and feeding habits of birds as suggested by Smith (1992).In the Arbegona Garemba forest study area, where knifofia foliosa, strawberry, hypericum revoltum and giant lobelia were dominant, the Variable sunbird (Corvus crassirostris), Red winged starling (Buphagusery throrhynchus), Malachite sunbird (Gypaetus barbatus) and Takazze sun bird (Passer swainsonii) were commonly associated as eating and resting site.

As these species depended on sucking nectar and they require such vegetation for resting and watching to perch and capture the prey.

This result in line with the results of Estades, 1997 that shows, within smaller sub-groups of sites, some bird 
species were more associated with a particular plant species: fruit trees, flowering trees, bushes or shrubs. Lammargier (Emberizas triolata) bird species was highly associated with cliff and in accessible areas for resting and to escape from enemy.

In Arbegona Garemba forest, there was variation in species richness and abundance as vegetation height varies. Difference between average species richness and individuals and the vegetation height was significant in both Arbegona Garemba forest. The numbers of vegetation associates at different height intervals were indicative of vegetation density that was related with bird diversity. Many researchers have written differently on the relationship between bird diversity and vegetation types. MacArthur and his followers stated that vegetation type and structure is more closely connected to bird species diversity than floristic composition (MacArthur, 1964).

As the vegetation layer increases, the number of available niches for birds also increases and so does the diversity of avian species. This is due to the different feeding habit of birds leading to niche separation (MacArthur, 1964).

Primary topographic factors (eg. Slope, aspect, elevation) alter micro climatic conditions and indirectly affect the growth and distribution of land cover (vegetation), hence affecting bird distribution and abundance. This in line with McCain (2009) that reported general decrease in species richness and abundance along the elevation gradient.

The decrease in abundance and species richness as vegetation height increases could be as a result of decrease in heterogeneity in habitat type, absence of fruiting trees and risk of predation that could be higher in natural forest.

Other study support this, as birds were more abundant in heterogeneous habitats than homogenous forest (Pennington and Blair, 2011; Shochat et al., 2010).

\section{CONCLUSION AND RECOMMENDATIONS}

The remnant patch forest and its surrounding areas of Arbegona garemba fragment is an important nature reserve for migratory species and home to endemic and near-endemic species. The distribution of avian species is closely related to type of the habitat, which is influenced by environmental factors such as rainfall, altitude, slope, and temperature. It has been revealedin the results that birds' abundance is affected by the availability of food and cover, which is influenced mainly by vegetation composition and structure. Conserving the habitats as well as the species has great biological and social values. Therefore, to maintain the habitat and the avifauna species, the following recommendations are forwarded:

$>$ Conservation work through community participation should be properly developed and practiced.

$>$ As abundance and distribution of the bird species is determined by abundance and distribution of vegetation, equal conservation priority should be given to the bird habitats.

$>$ Further study especially on smaller and cryptic bird species needs to be conducted with the other ecological aspects to provide more information on the diversity of birds in the area.

\section{Acknowledgement}

This study was sponsored by Wondo Genet College of Forestry and Natural Resources, Hawassa University.

\section{REFERENCES}

Aerts, R., F. Lerouge, E. Novmber, L. Lens, M. Hermay and B. Muys. 2008. Land rehabilitation and the conservation of birds in a degraded Afromontane landscape in northern Ethiopia.Biodiversity and Conservation 17: 53-69.

Afework Bekele and Shimelis Aynalem. 2009. Species composition, relative abundance and Habitat association of the bird fauna of the montane forest of Zegie Peninsula and nearby Islands, Lake Tana, Ethiopia. SINET: Ethiopian Journal of Science 32:45-56.

AWAO. 2007. Annual Report. Arbegona, Ethiopia 18-22.

AWCTO. 2009. Annual Report. Arbegona, Ethiopia 5-8.

Bibby, C. J., Burgess, N. D and D. Hills. 1992. Birds census technique. Tokyo, Toronto. Academic press 30: 8696.

Bibby, C.J., S. Marsden, and M. Jones. 1998. Bird surveys. Expedition Advisory Centre.

Clout, M.N. and J.R. Hay. 1989. The importance of birds as browsers, pollinators and seed dispersers in New Zealand forest. New Zealand journal of ecology.27-33.

EBI. 2015. Ethiopia's national biodiversity strategy and action plan, Addis Ababa ,Ethiopia, 2015-2020.

ESRI . 2012. Arc GIS software 10.1. Environmental Systems Research Institute. California.

Estades, F.C. 1997. Bird-habitat relationships in vegetation gradient in the Andes of centeral Chile. Condor 99: 719-727.

Feleke Assefa ,Teka Tadesse and Abeba Dancho. 2015. Challenges and Opportunities of Village Poultry 
Production in Arbegona Garemba forest District , Sidama Zone, Southern Ethiopia. Department of Animal and Range Sciences, College of Agriculture, Wolaita Sodo University, Addis Ababa, Ethiopia.

Girma Mengesha and Afework Bekele. 2008. Diversity and relative abundance of birds of Alatish National Park. International Journal of Ecology and Environmental Sciences 34:215-222.

Girma Mengesha, Yosef Mamo and Afework Bekele. 2011. A comparison of terrestrial bird community structure in the undisturbed and disturbed areas of the Abijata Shalla lakes national park, Ethiopia. International Journal of Biodiversity and Conservation 3:389-404.

Lee, P.Y. and J.T. Rotenberry. 2005. Relationships between bird species and tree species assemblages in forested habitats of north eastern America. Journal of Biogeography 32:1139-1150.

MacArthur, R.H. 1964. Environmental factors affecting bird species diversity. American Naturalist 98: 387-397.

McCain, C. M. 2009. Global analysis of bird elevation diversity. Global Ecology and Biogeography 18: 346-360.

Rodríguez-Estrella, R.2007 . Land use changes affect distributional patterns of desert birds in the Baja California peninsula, Mexico. Diversity and distribution 13:877-889.

Sekercioglu, C. 2012. Bird functional diversity and ecosystem services in tropical forest, agro forest and agricultural areas. Journal of Ornithology 153:153-161.

Shimelis Aynalem and Afework Bekele. 2008. Species composition, relative abundance and distribution of bird fauna of riverine and wetland habitats of Infranz and Yiganda at Southern tip of Lake Tana, Ethiopia. Tropical Ecology 49: 199-209.

Weldemariam Tesfahunegn, 2006. A guide to a complete annotated checklist of the birds of Ethiopia.

Zerihun Girma, George Chuyong, Paul Evangelista and YosefMamo. 2015. Habitat Characterization and Preferences of the Mountain Nyala (TragelaphusBuxtoni, Lydekker 1910) and Menelik's Bushbuck (Tragelaphus Scriptus Meneliki, Neumann 1902) in Arsi Mountains National Park, South-Eastern Ethiopia. International Journal of Current Research 7: 23074-23082. 
Appendix 1: Bird Species Recorded at Geremba Mountain Fragment (a, Near Endemic c, endangered b, Endemic e, near threatened NM, Northern Migratory AM, Inter-African migrant)

\begin{tabular}{|c|c|c|c|c|c|c|c|c|}
\hline \multirow[t]{2}{*}{ Order } & \multirow[t]{2}{*}{ Family } & \multirow[t]{2}{*}{ Common name } & \multirow[t]{2}{*}{ Scientific Name } & \multicolumn{3}{|c|}{ Abundance } & \multirow[b]{2}{*}{$\begin{array}{l}\text { RA } \\
(\%)\end{array}$} & \multirow[b]{2}{*}{ Rank } \\
\hline & & & & Wet & Dry & Total & & \\
\hline Passeriformes & Estrildidae & Yellow bellied waxbill & Coccopygia quartinia & 17 & 22 & 39 & 6.31 & $1^{\text {st }}$ \\
\hline Passeriformes & Turdidae & Alpine chat & Cercomela sordida & 20 & 19 & 39 & 6.31 & $1^{\text {st }}$ \\
\hline Passeriformes & Rallidae & Rupels robin chat & Cossypha semirufa & 20 & 15 & 35 & 5.66 & $3^{\text {rd }}$ \\
\hline Passeriformes & Zosteropidae & Mountain thrush & Turdus olivaceus & 16 & 15 & 31 & 5.02 & $4^{\text {th }}$ \\
\hline Passeriformes & Nectariniidae & Wattled Ibis & Cinnyris venustus ${ }^{\mathbf{a}}$ & 14 & 12 & 26 & 4.21 & $5^{\text {th }}$ \\
\hline Columbiformes & Columbidae & Streaky seed eater & Columba guinea & 17 & 9 & 26 & 4.21 & $5^{\text {th }}$ \\
\hline Passeriformes & Passeridae & Takazze sun bird & Passer swainsonii & 17 & 6 & 23 & 3.72 & $7^{\text {th }}$ \\
\hline Passeriformes & Buphagidae & Red winged starling & Buphagus erythrorhynchus & 15 & 7 & 22 & 3.56 & $8^{\text {th }}$ \\
\hline Passeriformes & Sylviidae & Cinnamon bracken warbler & Batis minor & 11 & 8 & 19 & 3.07 & $9^{\text {th }}$ \\
\hline Passeriformes & Alaudidae & Thick billed raven & Galerida theklae $e^{\mathbf{a}}$ & 10 & 7 & 17 & 2.75 & $10^{\text {th }}$ \\
\hline Passeriformes & Nectariniidae & Montane white eye & Nectarinia famosa & 6 & 11 & 17 & 2.75 & $10^{\text {th }}$ \\
\hline Passeriformes & ploceidae & Baglafecht weaver & Ploceus baglafecht & 11 & 5 & 16 & 2.59 & $12^{\text {th }}$ \\
\hline Passeriformes & Sylviidae & Brown rumped seed eater & Parisoma lugens & 10 & 6 & 16 & 2.59 & $12^{\text {th }}$ \\
\hline Falconiformes & Accipitridae & Tawny flanked prinia & Aquila rapax & 8 & 5 & 13 & 2.10 & $14^{\text {th }}$ \\
\hline Galliformes & phasianidae & Chestnut naped francolin & Bubo capensis & 7 & 6 & 13 & 2.10 & $14^{\text {th }}$ \\
\hline Passeriformes & Corvidae & Variable sun bird & Corvus crassirostris & 10 & 2 & 12 & 1.94 & $16^{\text {th }}$ \\
\hline Passeriformes & Fringillidae & Bush petronia & Crithagra tristriatus & 7 & 4 & 11 & 1.78 & $17^{\text {th }}$ \\
\hline Galliformes & phasianidae & Chinspot batis & Pternistis castaneicollis & 11 & 0 & 11 & 1.78 & $17^{\text {th }}$ \\
\hline Coraciiformes & Bucerotidae & Dusky turtle dove & Tockus alboterminatus & 2 & 9 & 11 & 1.78 & $17^{\text {th }}$ \\
\hline Passeriformes & Cisticolidae & Green backed eremomela & Camaroptera brachyura & 8 & 2 & 10 & 1.62 & $20^{\text {th }}$ \\
\hline Passeriformes & Motacillidae & Yellow breasted apalis & Motacilla flavida & 6 & 3 & 9 & 1.46 & $21^{\text {th }}$ \\
\hline Passeriformes & Sylviidae & Ground scraper thrush & Eremomela canescens & 5 & 4 & 9 & 1.46 & $21^{\text {th }}$ \\
\hline Passeriformes & Accipitridae & Malachite sun bird & Gypaetus barbatus & 5 & 4 & 9 & 1.46 & $21^{\text {th }}$ \\
\hline Passeriformes & paridae & White backed black tit & Parus leuconotus & 5 & 4 & 9 & 1.46 & $21^{\text {th }}$ \\
\hline Passeriformes & Muscicapidae & Abyssinian slaty fly catcher & Melaenornis chocolatina $^{\mathbf{a}}$ & 4 & 3 & 7 & 1.13 & $25^{\text {th }}$ \\
\hline Passeriformes & Muscicapidae & Scaly francolin & Cossypha semirufa & 3 & 4 & 7 & 1.13 & $25^{\text {th }}$ \\
\hline Columbiformes & Columbidae & African olive pegion & Columba arquatrix & 0 & 7 & 7 & 1.13 & $25^{\text {th }}$ \\
\hline Piciformes & Indicatoridae & Green backed cameroptera & Indicator indicator & 5 & 1 & 6 & 0.97 & $28^{\text {th }}$ \\
\hline Passeriformes & Monarchidae & African dusk flycatcher & Muscicapa adusta & 4 & 2 & 6 & 0.97 & $28^{\text {th }}$ \\
\hline Passeriformes & Fringillidae & Swaisons sparrow weaver & Serinus striolatus & 3 & 3 & 6 & 0.97 & $28^{\text {th }}$ \\
\hline Passeriformes & Turdidae & Abyssinian ground thrush & Zoothera piaggiae & 2 & 4 & 6 & 0.97 & $28^{\text {th }}$ \\
\hline Passeriformes & Passeridae & Cape crow & Petronia dentata & 2 & 4 & 6 & 0.97 & $28^{\text {th }}$ \\
\hline Passeriformes & Pipridae & Barn swallow & Manacus manacus & 4 & 1 & 5 & 0.81 & $33^{\text {th }}$ \\
\hline Passeriformes & Muscicapidae & Tawny eagle & Nectarinia tacazze & 3 & 2 & 5 & 0.81 & $33^{\text {th }}$ \\
\hline Passeriformes & Fringillidae & African citril & Serinus citrinelloides & 2 & 3 & 5 & 0.81 & $33^{\text {th }}$ \\
\hline Falconiformes & Accipitridae & Augur buzzard & Buteo augur & 3 & 2 & 5 & 0.81 & $33^{\text {th }}$ \\
\hline Columbiformes & Columbidae & Fantailed raven & Streptope lialugens & 4 & 1 & 5 & 0.81 & $33^{\text {th }}$ \\
\hline Coliiformes & Collidae & Speckled pegion & Colius striatus & 3 & 2 & 5 & 0.81 & $33^{\text {th }}$ \\
\hline Coliiformes & Apodidae & African black swift & Apus parvus & 5 & 0 & 5 & 0.81 & $33^{\text {th }}$ \\
\hline Passeriformes & Cisticolidae & Yellow bellied eremomela & Eremomela icteropygialis & 5 & 0 & 5 & 0.81 & $33^{\text {th }}$ \\
\hline Passeriformes & Estrildidae & Common waxbill & phylloscopus collybita & 3 & 2 & 5 & 0.81 & $33^{\text {th }}$ \\
\hline Passeriformes & Nectariniidae & Pallid harrier & Cyanomitraolivacea & 1 & 3 & 4 & 0.65 & $42^{\text {th }}$ \\
\hline Passeriformes & Sylviidae & Willow warbler & Phylloscopus trochilus & 1 & 3 & 4 & 0.65 & $42^{\text {th }}$ \\
\hline Accipitriformes & Accipitridae & Pied crow & Circus macrourus & 2 & 2 & 4 & 0.65 & $42^{\text {th }}$ \\
\hline Piciformes & Accipitridae & Greater honey guide & Accipiter melanoleucus & 2 & 2 & 4 & 0.65 & $42^{\text {th }}$ \\
\hline Falconiformes & Emberizidae & Lammargier & Emberiza striolata & 2 & 2 & 4 & 0.65 & $42^{\text {th }}$ \\
\hline Passeriformes & Turdidae & Olive sun bird & Turdus olivaceus & 3 & 0 & 3 & 0.49 & $48^{\text {th }}$ \\
\hline Passeriformes & Muscicapidae & Speckled mouse bird & Melaenornis pammelania & 2 & 1 & 3 & 0.49 & $48^{\text {th }}$ \\
\hline Passeriformes & Motacillidae & Yellow wagtail $^{\text {NM }}$ & Motacilla flava & 1 & 2 & 3 & 0.49 & $48^{\text {th }}$ \\
\hline Passeriformes & Monarchidae & *African paradise flycatcher ${ }^{\mathbf{A M}}$ & Terpsiphone viridis & 0 & 3 & 3 & 0.49 & $48^{\text {th }}$ \\
\hline Passeriformes & Turdidae & Hooded volture & Psophocichla litsipsirupa ${ }^{\mathbf{c}}$ & 0 & 5 & 3 & 0.49 & $48^{\text {th }}$ \\
\hline Falconiformes & Accipitridae & House bunting & Necrosyrtes monachus & 3 & 0 & 3 & 0.49 & $48^{\text {th }}$ \\
\hline Psittaciformes & Sylviidae & Collared sun bird & Bradypterus cinnamomeus & 3 & 0 & 3 & 0.49 & $48^{\text {th }}$ \\
\hline Piciformes & Indicatoridae & Southern black fly catcher & Indicator variegatus & 2 & 0 & 2 & 0.32 & $55^{\text {th }}$ \\
\hline Pelecaniformes & Threskiornithidae & White and black manninkin & Bostrychia carunculata & 2 & 0 & 2 & 0.32 & $55^{\text {th }}$ \\
\hline Passeriformes & Hirundinidae & Black chested snake eagle & Hirundo rustica & 2 & 0 & 2 & 0.32 & $55^{\text {th }}$ \\
\hline Passeriformes & Nectariniidae & Common bulbul & Hedydipna collaris & 2 & 0 & 2 & 0.32 & $55^{\text {th }}$ \\
\hline Passeriformes & 'Pycnonotidae & Common chifchaff & Pycnonotus barbatus & 2 & 0 & 2 & 0.32 & $55^{\text {th }}$ \\
\hline Passeriformes & 'Sturnidae & Rougets rail & Onychognathus morio ae & 2 & 0 & 2 & 0.32 & $55^{\text {th }}$ \\
\hline Passeriformes & Cisticolidae & Thekla lark & Prinia subflava & 2 & 0 & 2 & 0.32 & $55^{\text {th }}$ \\
\hline Passeriformes & Estrildidae & Crowned hornbill & Estrilda astrild & 1 & 1 & 2 & 0.32 & $55^{\text {th }}$ \\
\hline Galliformes & Phasianidae & Scaly throated honey guide & Pternistis squamatus & 2 & 0 & 2 & 0.32 & $55^{\text {th }}$ \\
\hline Psittaciformes & Accipitridae & Black winged Love bird & Milvus migrans $\mathbf{a}^{\mathbf{a}}$ & 2 & 0 & 2 & 0.32 & $55^{\text {th }}$ \\
\hline Passeriformes & Corvidae & Red billed oxpecker & Corvus albus & 2 & 0 & 2 & 0.32 & $55^{\text {th }}$ \\
\hline Psittaciformes & Psittaculidae & Blue headed coucal & Agapornis taranta & 2 & 0 & 2 & 0.32 & $55^{\text {th }}$ \\
\hline Psittaciformes & Corvidae & Cape eagle owl & Corvus capensis & 1 & 1 & 2 & 0.32 & $55^{\text {th }}$ \\
\hline Passeriformes & Accipitridae & Black kite & Circaetus pectoralis & 0 & 2 & 2 & 0.32 & $55^{\text {th }}$ \\
\hline Passeriformes & Corvidae & Great sparrow hawk & Corvus rhipidurus & 1 & 0 & 1 & 0.16 & $69^{\text {th }}$ \\
\hline Cuculiformes & Cuculidae & Brown parisoma & Centropus monachus & 1 & 0 & 1 & 0.16 & $69^{\text {th }}$ \\
\hline Apodiformes & Apodidae & *Alpine swift ${ }^{\mathrm{NM}}$ & Tachymarptis melba & 1 & 0 & 1 & 0.16 & $69^{\text {th }}$ \\
\hline Accipitriformes & Accipitridae & Yellow billed kite & Milvus aegyptius & 1 & 0 & 1 & 0.16 & $69^{\text {th }}$ \\
\hline Accipitriformes & Timaliidae & Abyssinian cat bird & Parophasma galinieri ${ }^{\mathbf{b}}$ & 1 & 0 & 1 & 0.16 & $69^{\text {th }}$ \\
\hline Falconiformes & Falconidae & African hobby & Falco cuvierii & 1 & 0 & 1 & 0.16 & $69^{\text {th }}$ \\
\hline
\end{tabular}

